\title{
Oestrogen and cortisol producing adrenal tumour
}

\author{
Ali A M Ghazi, Djafar Mofid, Farzaneh Rahimi, Hasan Marandi, Hamid Nasri, \\ Susan Afghah
}

\begin{abstract}
A 14 year old boy is presented who was admitted to the psychiatric ward because of delirium. He also had gynaecomastia, facial oedema, striae, and hypertension. He was finally proved to have a mixed oestrogen and cortisol producing adrenal tumour which was removed surgically with complete improvement and no relapse.

(Arch Dis Child 1994; 71: 358-359)
\end{abstract}

Mixed oestrogen and cortisol producing adrenal tumours in boys are very unusual and only one case has previously been reported. ${ }^{1}$ In this paper we report a 14 year old boy who was at first admitted to a psychiatric ward because of abnormal behaviour, he also had a very obvious bilateral gynaecomastia. Further evaluation confirmed that the patient had a mixed oestrogen and cortisol producing adrenal tumour.

\section{Case report}

A 14 year old boy was admitted to the psychiatric ward because of aggressive behaviour and delirium. He was well until one year before when a general increase in weight and bilateral gynaecomastia began to develop. For the previous four weeks his parents had noted his abnormal behaviour with the patient hitting his head against the wall, breaking windows, talking nonsense, acting aggressively, and suicidal ideation. Psychiatric evaluation disclosed that the patient was irritable, a persecutory delusion was obvious, perception was normal, and recent and immediate memory was quite disrupted. He gradually became lethargic and developed coma.

After referral to an endocrinologist because of moon face, buffalo hump, purplish striae of the abdomen and groin, and hypertension (blood pressure $150 / 100 \mathrm{~mm} \mathrm{Hg}$ ) Cushing's syndrome was diagnosed. On

Table 1 Results of hormonal evaluation of the patient before surgery

\begin{tabular}{|c|c|c|c|c|}
\hline & \multirow[b]{2}{*}{ Baseline } & \multicolumn{3}{|l|}{ Suppression test } \\
\hline & & $\begin{array}{l}\text { Low dose } \\
\text { dexamethasone }\end{array}$ & $\begin{array}{l}\text { High dose } \\
\text { dexamethasone }\end{array}$ & $\begin{array}{l}\text { Normal } \\
\text { range }\end{array}$ \\
\hline \multicolumn{5}{|l|}{ Cortisol } \\
\hline Serum $(\mathrm{nmol} / \mathrm{l})$ & 803 & 944 & 908 & $138-690$ \\
\hline 24 Hour urine (nmol/day) & 1139 & 3079 & 200 & $<276$ \\
\hline 24 Hour urine 17 -hydroxy steroids ( $\mu \mathrm{mol} /$ day) & 76 & 159 & 116 & $8 \cdot 3-44 \cdot 0$ \\
\hline 24 Hour urine 17 -ketosteroids $(\mu \mathrm{mol} /$ day) & 50 & 182 & $75 \cdot 5$ & $20-70$ \\
\hline Serum oestradiol $(\mathrm{pmol} / \mathrm{l})$ & 958 & - & - & $<184$ \\
\hline Serum testosterone $(\mathrm{nmol} / \mathrm{l})$ & 0.75 & - & - & $9 \cdot 4-37 \cdot 0$ \\
\hline Serum prolactin $(\mu \mathrm{g} / \mathrm{l})$ & $81 \cdot 4$ & - & - & $0 \cdot 2-9 \cdot 4$ \\
\hline Serum $17 \alpha$-hydroxy progesterone (nmol/l) & $1 \cdot 7$ & - & - & $0 \cdot 6-5 \cdot 4$ \\
\hline Serum adrenocorticotrophic hormone $(\mathrm{pmol} / \mathrm{l})$ & $6 \cdot 8$ & - & - & $0-19 \cdot 8$ \\
\hline Serum dehydroepiandrosterone sulphate $(\mu \mathrm{mol} / \mathrm{l})$ & $3 \cdot 6$ & - & - & $4 \cdot 9-12 \cdot 5$ \\
\hline
\end{tabular}

physical examination moderate central obesity and massive bilateral gynaecomastia were noted. His pubic hair was Tanner grade 3 and genital organs were small for his age (testicular diameter less than $2 \mathrm{~cm}$ ). Routine laboratory tests gave normal results; results of hormone analysis are shown in table 1 . Because of nonsuppressibility of serum and urine steroids an adrenal tumour was considered. Intravenous pyelography showed displacement of the upper pole of the right kidney. Adrenal sonography and computed tomography revealed a tumour on the right side. The patient was operated on and a $5 \times 8 \mathrm{~cm}, 103 \mathrm{~g}$ tumour was removed. An adrenal venous sample was taken during the operation and the results are shown in table 2 . Bilateral mastectomy was performed during the same session. Postoperatively the patient's consciousness and orientation to time and place improved gradually. Two months after surgery psychiatric evaluation gave normal results and after one year he was found to be completely normal from a psychiatric and general point of view.

\section{Discussion}

Secreting adrenal tumours in childhood and adolescence are rare and make up only $2 \%$ of childhood tumours. ${ }^{2}$ Oestrogen producing tumours are the least common among these neoplasms and we could find only 13 published cases in boys under the age of 15 years. ${ }^{3-6}$ Eight of these patients had pure oestrogen producing tumours, four had a mixed oestrogen and androgen producing tumour, and only one case had a mixed oestrogen and cortisol producing tumour. Ages of the patients ranged from 3.5 to 15 years and nine of them were between 5 and 7 years old. All the patients had gynaecomastia and in those with mixed oestrogen and androgen producing tumours, penile enlargement and increased facial hair were noted.

In two patients the tumours were big enough to be palpated clinically. Intravenous

Department of

General Surgery

D Mofid

Department of

Psychiatry

H Marandi

S Afghah

Department of

Pathology

F Rahimi

Correspondence and reprint requests to: $\mathrm{Dr}$ Ali A M Ghazi, Endocrine Researc Center, PO Box 193954763, Eveen, Tehran, Iran Accepted 20 July 1994 
Table 2 Result of hormonal evaluation of the adrenal venous sample

Cortisol (nmol/1) Oestradiol (pmol/l)

Testosterone (nmol/l)

Dehydroepiandrosterone sulphate ( $\mu \mathrm{mol} /)$

Prolactin $(\mu \mathrm{g} / \mathrm{l})$

218

pyelography, pneumoretroperitoneum, ultrasonography, or computed tomography were used for localisation of the tumours.

In laboratory evaluations of these patients, serum or urine oestrogen was raised in those who were measured. In the case reported by Sultan et al and in our case, tumoral and adrenal vein analysis disclosed a very high concentration of oestradiol. This finding is important because it confirms that the source of oestrogen is the tumour itself and not peripheral aromatisation of precursor substances. In nine patients tumours were located on the left and in five on the right side.

While microscopic findings are not always sufficient to establish the diagnosis of their benign or malignant behaviour, weight or diameter of the tumours are used as markers to predict their outcome.

Generally, tumours weighing more than $100 \mathrm{~g}$ or having a diameter of more than $6 \mathrm{~cm}$ are considered malignant. Keeping this in mind 10 patients had an adenoma and four a carcinoma. The outcome of the tumours seem to be more favourable in children in comparison with adults and 11 out of 14 patients were alive without recurrence of the tumour between one to 14 years after removal of the tumours.

Some points in our case merit special considerations:

(1) This is the first case where the presentation was acute psychosis, and with respect to the one year history of gynaecomastia and the recent onset of cutaneous stria, hypertension and psychiatric problems, we can conclude that the tumour changed from a pure oestrogen producing to a mixed oestrogen and cortisol producing neoplasm.

(2) Adrenal vein sampling showed that oestradiol, hydrocortisone, testosterone, and prolactin were directly secreted from the tumour. Lack of peripheral effects of testosterone in our case may be from either high amounts of oestradiol or conversion of testosterone to oestrogens in peripheral tissues.

(3) Completion of puberty one year after surgery with an increase in testicular size and male type muscular development indicate tumour eradication and pituitary recovery from the suppressive effects of oestradiol, testosterone and hydrocortisone, though long term follow up is necessary for the better understanding of the course and prognosis.

We thank Mrs Nafarabadi and Mrs Arbab for laboratory assistance and Miss T Fakhimi for preparation of the manuscript.

1 Picard MMR, Horeau J, Kerneis J, Hardy M, Guinot U, Ranger J. Tumor cortico-surrenale chez un garcon de 14 ans avec hypefiollicularism, confrantations cliniques et biologiques. Societe medicale des hopitaux de Paris, biologiques. Societe medicale des

2 Bongiovani AM. Tumors or the adrenal cortex. In: Kaplan SA, ed. Clinical pediatrics and adolescent endocrinology. Philadelphia: WB Saunders, 1982: 171-86.

3 Howard CP, Takahashi H, Hayles AB. Feminizing adrenal adenoma in a boy, case report and literature review. Mayo Clin Proc 1977; 52: 354-7.

4 Sultan C, Descomps B, Garandeu P, Bressot N, Jean R. Pubertal gynecomastia due to an estrogen producing adrenal adenoma. F Pediatr 1979; 95: 744-7.

5 Desai MB, Kapadia SN. Feminizing adrenocortical tumors in male patients: adenoma versus carcinoma. $\mathcal{f}$ Urol 1988; 139: $101^{-3}$.

6 Itam RM, Amudson GM, Kaplan SA, Lippe BM. Prepubertal gynecomastia caused by an adrenal tumor. Am F Dis Child 1982; 136: 584-6. 